\title{
Economic impacts of Covid-19 on the labor market and human capital
}

\author{
Marek Dvořák \\ Czech University of Life Sciences Prague, Prague, Czech Republic, e-mail: dvorakmarek@pef.czu.cz \\ Patrik Rovný \\ Slovak University of Agriculture in Nitra, Nitra, Slovak Republic, e-mail: patrik.rovny@uniag.sk
}

Veronika Grebennikova

Kuban State University, Krasnodar, Russia, e-mail:vmgrebennikova@mail.ru

Marina Faminskaya

Russian State Social University, Moscow, Russia, e-mail: faminskaya@mail.ru

Citation: Dvořák, M., Rovný, P., Grebennikova, V., Faminskaya, M. (2020). Economic impacts of Covid-19 on the labor market and human capital. Terra Economicus, 18(4), 78-96. D0I: 10.18522/2073-6606-2020-18-4-78-96

This paper tackles the economic impacts of COVID-19 pandemic on the labor markets and human capital. Specifically, it looks into the issues the pandemic brought upon the human resources and personnel during coronavirus lockdowns. Our results identify that in spite of all the adverse effects of the pandemic such as the excessive burden on the healthcare system, great economic losses and disruptions on the labor market (such as the loss of human capital and widening gaps in gender inequality) due to the lockdowns in many countries intended to slow down the spread of the infection with the purpose of flattening the curve representing the numbers of the COVID-19 patients, the current situation had many positive economic effects. For instance, we find that the recent pandemic helped to increase the financial inclusion and enabled broader access to financial system. In addition, during the past few months, digitalization and the use of information technology deepened and progressed in both large and small enterprises as well as in the higher education institutions. Moreover, COVID-19 pandemic helped to develop the awareness about the climate change among many people by demonstrating how the decrease in economic activity can have a profound effect on cutting $\mathrm{CO2}$ emissions. Furthermore, we find that COVID-19 pandemic contributed to optimizing work load and cutting unnecessary work in many large and small business companies and public institutions. It is likely that most of them will continue with this optimization and digitalization of work after the pandemic is over. Last but not least, we note the enhanced family life and interpersonal relations that would without any doubt contribute to the quality of human capital and the level of happiness. Our results might be useful for public officials and labor market specialists who would want to grasp the consequences of the COVID-19 pandemic and to find ways how to smoothen its impacts.

Keywords: labor market; COVID-19; human capital; economic impact; pandemic; personnel security

Acknowledgement: The study was funded by the Russian Foundation for Basic Research (RFBR) and the Krasnodar Territory of the Russian Federation, project No. 19-413-230017.

JEL codes: J20; J24; M45; P36

() М. Дворжак, П. Ровны, В. Гребенникова, М. Фаминская, 2020 


\title{
Экономическое воздействие Covid-19 на рынок труда и человеческий капитал
}

\author{
Марек Дворжак \\ Чешский университет естественных наук в Праге, г. Прага, Чехия, e-mail: dvorakmarek@pef.czu.cz
}

Патрик Ровньт

Словацкий сельскохозяйственный университет в Нитре, г. Нитра, Словакия, e-mail: patrik.rovny@uniag.sk

\section{Вероника Гребенникова}

Кубанский государственный университет, г. Краснодар, Россия, e-mail: vmgrebennikova@mail.ru

\section{Марина Фаминская}

Российский государственный социальный университет, г. Москва, Россия, e-mail: faminskaya@mail.ru

Цитирование: Dvořák, M., Rovný, P., Grebennikova, V., Faminskaya, M. (2020). Economic impacts of Covid-19 on the labor market and human capital. Terra Economicus, 18(4), 78-96. DOI: $10.18522 / 2073-6606-2020-18-4-78-96$

В нашей статье рассматриваются экономические последствия пандемии COVID-19 для рынков труда и человеческого капитала. Наши результаты показывают, что, несмотря на все неблагоприятные последствия пандемии, такие как чрезмерная нагрузка на систему здравоохранения, ощутимый экономический ущерб и сбои на рынке труда (например, потери человеческого капитала и увеличение разрыва в гендерном неравенстве), обусловленные локдауном во многих странах, направленным на замедление распространения инфекции с целью сглаживания кривой, отражающей количество пациентов с COVID-19, нынешняя ситуация имела множество положительных экономических эффектов. Например, мы обнаружили, что недавняя пандемия способствовала расширению финансовой инклюзии. Кроме того, за последние несколько месяцев цифровизация и использование информационных технологий стали интенсивнее развиваться как на крупных, так и на малых предприятиях, а также в высших учебных заведениях. Более того, пандемия COVID-19 помогла повысить осведомленность об изменении климата среди многих людей, продемонстрировав, как снижение экономической активности может влиять на сокращение выбросов CO2. Кроме того, мы обнаружили, что пандемия COVID-19 способствовала оптимизации рабочей нагрузки и сокращению ненужной работы во многих крупных и малых компаниях и государственных учреждениях. Вероятно, большинство из них продолжат эту оптимизацию и цифровизацию работы после того, как пандемия закончится. И последнее, но не менее важное: мы отмечаем улучшение семейной жизни и межличностных отношений, которые, без сомнения, будут способствовать повышению качества человеческого капитала и уровня счастья. Наши результать могут быть полезны государственным служащим и специалистам по рынку труда, которые хотели бы понять последствия пандемии COVID-19 и найти способы смягчить ее последствия.

Ключевые слова: рынок труда; COVID-19; человеческий капитал; экономическое влияние; пандемия; безопасность персонала

Благодарность: Работа выполнена при финансовой поддержке Российского фонда фундаментальных исследований (РФФИ) и Краснодарского края Российской Федерации, проект № 19-413-230017. 


\section{Introduction}

In spring 2020, the World Health Organization (WHO) announced that the world was facing a new pandemic - an unprecedented spread of the new coronavirus known as SARS-CoV-2 or COVID-19. Even though various infectious diseases already appeared many times before in human history and inflicted a varying degree of damage (e.g. the Spanish flu caused by the H1N1 influenza A virus that killed between 17 and 50 million people worldwide in 1917-1918 (Short et al., 2018)), the COVID-19 pandemic became a unique precedence (see e.g. Abbott et al., 2020; Besenyő et al., 2020; Sahin et al., 2020; or Rezk et al., 2020). Thanks to the spread of Internet and information and communication technologies (ICT), it became the first pandemic to be followed, reported on and commented upon in real time (Ye, 2002; Ndiaye et al., 2020). It was due to the wide media coverage and information flow that it soon began influencing consumer behaviour by bringing fear and uncertainty and therefore deteriorating markets. Labor market and human capital were the first to feel these effects due to the rising unemployment, job insecurity and the shrinking career opportunities due to the spread of COVID-19 all around the world (Costa Dias et al., 2020; Lemieux et al., 2020).

The unprecedented impact of COVID-19 on the economic and social relations all around the world as well as on the labor markets was to in many ways due to the ongoing globalization that made the transmission of the virus across continents a matter of weeks and days. Globalization might be viewed as a useful feature of the progress but it also has its adverse effects that might result in job loss, deprivation, and economic downturns, as many examples show (Kalyugina et al., 2020). In fact, many researchers now express the idea that COVID-19 pandemic might be the factor that halted or even stopped the ongoing globalization, a process of an unprecedented scale we were facing in the $21^{\text {st }}$ century (see e.g. Gruszczynski, 2020; or Bhusal, 2020; or Razif et al., 2020).

It is becoming apparent now that the consequences of COVID-19 pandemic for the labor market are going to be long-running. This is the fact many researchers can agree upon (Foss, 2020; Al-Fad$l y, 2020)$. Even assuming that the economic contraction comes to an end, an economy such as the United States would need several months to return to pre-contraction economic performance and to regain stable labor demand. It is estimated that it could take up to two years for the country to return to the level of unemployment before COVID-19, and that full recovery from its current state could take much longer (Cutler, Summers, 2020). Job losses caused by the COVID-19 pandemic are expected to be a long time coming, with the number of unemployed likely to more than double by 2020. Since April 2020, when the order of residence - at home - was set, 23.1 million Americans have been unemployed, an increase of 1.2 million from the previous month ${ }^{1}$. The U.S. labor market recovered in the first months of the coronavirus pandemic, but has since recovered and is beginning to recover. The rise in infections in recent weeks could cause a major shock in job losses. As the number of COVID-19 infections levelled off and home orders were lifted, that number fell by 5.3 million (Bartin et al., 2020a). The shops closed in March and April 2020 have resumed operations and the shops open in April and May. Some authors are currently working on a study to examine how the employer shutdown affects the U.S. economy. According to some evidence employers are cutting and skipping each other's pay raises. These events could cause employers to lay off workers which would prolong the labor market's recovery from these events. After an initial poor start, they often get stuck in low-paying, low-quality jobs. If jobs are destroyed, it will take time for workers to find good jobs they want to keep. Even as the economy strengthens, it will be difficult for workers to catch up with their pre-recession cohorts. Bartik et al. (2020b) found that employment rates of graduates entering the U.S. labor market after 2010 persisted for many years, rather than fading. Compared with time - adjusted employment rate - they had an employment rate that was higher than the one we are seeing in 2019, but not nearly as high as otherwise predicted.

Our paper focuses on the issues caused by the COVID-19 pandemic to the labor market, human resources, and personnel security. It argues that in spite of all the adverse effect and the increased death toll, the pandemic has a number of positive outcomes. Section 2 discusses the state of the

White House (2020). Proclamation suspending entry of aliens who present a risk to the U.S. labor market following the coronavirus outbreak (https://www.whitehouse.gov/presidential-actions/proclamation-suspending-entry-aliens-present-risk-u-s-labor-market-following-coronavirus-outbreak/ - accessed on 28.11.2020). 
human resources and personnel security during coronavirus lockdown. Section 3 contemplates upon the gender inequality on the labor market in the times of COVID-19. Section 4 discusses the effect of COVID-19 on the financial inclusion and the broader access to the financial system. Section 5 provides the examples how the recent pandemic helped to increase digitalization and the use of information technology. Section 6 describes the effect for the enhanced awareness about the climate change. Section 7 relates how COVID-19 pandemic helped to cut redundant and unnecessary work. Section 8 explain how the pandemic changed the patterns of excessive travel and endless business meetings. Section 9 describes the positive effects of the enhanced family life due to COVID-19. Finally, section 10 comes with the closing remarks as well as conclusions and implications.

\section{Human resources and personnel security during lockdowns}

Recent pandemic contracted a devastating blow to the labor market and personnel security worldwide. Many people lost their jobs but most importantly the sense of insecurity and helplessness was even worse. In spring 2020, when no one knew anything about COVID-19 virus including its effects, mortality rates, features and peculiarities, there was no better option other than to lock oneself at home and work remotely. While this was acceptable for many professions including the office workers, teachers and lecturers, as well as IT specialists, hairdressers, bartenders, cooks, and assembly line workers could hardly do the same (Schlenz et al., 2020; Dobrowolski, 2020).

In general terms, competitiveness that constitutes an important element of any business environment suffered which might have long-term consequences (Abrham et al., 2015; Segota et al., 2017). As a result of the pandemic and lockdown some professions experienced more than a $100 \%$ boost, among them e-marketing and delivery services. E-marketing in particular proves to be an important element of the new business relations (Anser et a., 2020; Janšto et al., 2019) and it showed itself as very useful during the recent crisis.

Governments worldwide made enormous efforts to make the impact of social distancing and national lockdowns in an attempt to prevent the spread of the coronavirus infection as small as possible. Various supporting programs, payments, subsidies and funds were deployed in order to keep many employees afloat. This can explain quite low numbers of unemployment in many countries (see Fig. 1 that follows).

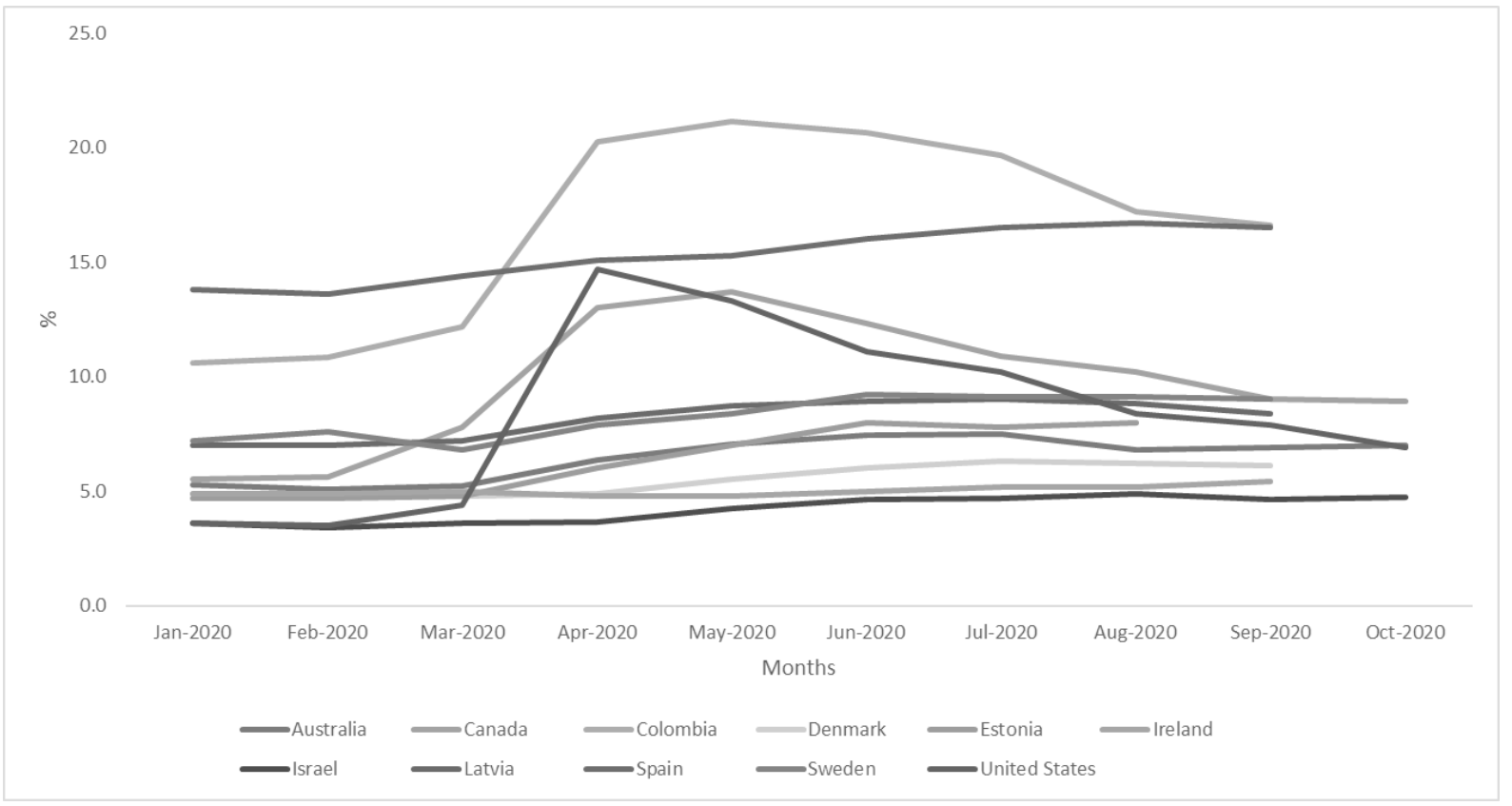

Fig. 1. Monthly unemployment rates in selected OECD countries (2020)

Source: 0 wn results based on OECD (2020). 
One can see that the highest spikes were recorded in Colombia, Canada and the United States, while the steadily high rate of unemployment in Spain followed the same trend from the previous year. Many European countries such as Ireland or Denmark did not yield high changes in the unemployment rate and the path remained more or less the same.

With regard to the above, it becomes obvious that information to employees about their employer's status during a government shutdown due to the COVID-19 should remain the focus of all employers. Human Resources (HR) specialists are to be made responsible for managing the day-to-day tasks of personnel in an emergency and have proven to be the means of unifying function in a crisis. As the lockdown situation changes in many countries (such as the trends in Russia, Poland, or the Czech Republic where the relatively calm period of easing restrictions occurred between the first and the second wave of coronavirus) and the restrictions unlock, the task for HR managers is to remain a trusted HR consultant while taking the lead on issues such as flexible working hours, sometimes in the face of pushbacks. Now more than ever, it is important to work with leaders and human resources experts as a first steps to ensure that we get back on our feet when the immediate threat of coronavirus is collectively contained. Many organizational and design professionals believe that this time of quickly forced work from home will change the working world indefinitely (Raisiene et al., 2020; Waizenegger et al., 2020). In view of the high-profile situation of the lockout and the potential for forced office closures, COVID-19 placed the remote working in the foreground of the political discussions on personnel policy.

Although remote work is already relatively common in many industries, not all companies are prepared for the sudden shift to a completely remote workforce. Since COVID-19 began, more and more companies have been working to protect their employees from domestic violence by performing emergency work. It is important that all employers have the right technical tools for the remote team now, but they also need to involve everyone and focus on their work. Most families have been quarantined, while staff are now being quarantined for much longer than they would normally be. Thence, it appears crucial that human resources chiefs must introduce fair hiring practices that can help prioritize hiring of those most affected by the effects of the COVID-19 pandemic (McGuire et al., 2020). Company leaders and human resources teams create change within the organization, as well as strong team structures. HR chiefs who should be used to achieve business continuity goals should remember that the threat posed by COVID-19 is still great. Managers, staff and administration must work closely together to reduce overheads and operating costs. To ensure the long-term sustainability of the business, business travel plans, resources and expenses are limited to reduce their expenditures. Managers will also have to make important decisions about future tasks, balancing the risks for employees with the need to continue to run business and provide services to customers. This sounds like a simple task, but monitoring every employee hourly around the world can be overwhelming.

On a practical level, the key is always to know where the staff are and where they are going. Alternatives to planned trips to affected areas should be considered, such as postponing trips or holding meetings via teleconferences. The most successful companies are switching to social media such as Facebook, Twitter, LinkedIn and other social networks to communicate with remote employees (Wang et al., 2020). They convey messages that show empathy, build trust and connect with workers who are now in a different working climate. The main job of HR managers at the moment is to keep their staff informed, calm down and build trust. While previous tactics and strategies will continue to be part of the human resources manager's toolkit for efficiently managing employees. However, we can now observe a major shift in the wake of the coronavirus that will fundamentally change the role of HR managers. The HR teams need to go to the top and be more attentive and competent about what to do while the staff are not in the office. Employees are trained to ensure seamless business operations by imparting knowledge of the importance of maintaining social distance. When employees enter and leave the office directive, they will also understand better when and how they leave the office directive and comply with it. While lives can be saved by limiting the transmission of COVID-19, it will put the well-being of employees, their well-being, at considerable risk. Industry workers might experience high levels of anxiety and stress, as they are at risk for the health of everyone else. 
All in all, it is important to enhance and improve the practices that companies apply and promote to improve employee well-being. All of these can improve employee health and well-being and support them mentally.

\section{COVID-19 and gender inequality on the labor market}

The United Nations (UN) very clear policy guidance sets out what governments and their populations need to do to ensure that the crisis of gender inequality does not worsen (Orzes et al., 2018). When the COVID-19 pandemic stroke, it rapidly started wiping out the limited and precious progress the world has made in gender equality over the past few decades (Power, 2020). The current predicament will exacerbate this persistent situation, and, although previous reports suggest that men are more likely to succumb to it, women around the world will have to pay the social and economic toll (Papadopoulos et al., 2020). Therefore, we argue in this paper that due to the recent situation should call for the protection of women's rights worldwide and to make sure that this pandemic does not destroy progress towards gender equality on the labor market. This includes building an equal future for women despite the pandemic, and ensuring that the socio-economic impact of COVID-19 is addressed, promoting transformative change and equality by addressing the care industry (paid and unpaid) and targeting women to address paid and unpaid care services in the economy.

One has to give some credit to the UN in trying to mitigate the situation. In responding to gender inequality through COVID-19, the United Nations have focused on many different areas, many of them in collaboration with the United Nations Office for the Coordination of Humanitarian Affairs (OCHA). They are working to raise awareness of this issue and to support the collection and evaluation of data in the areas of gender inequality, gender discrimination, sexual violence and equality (Ryan, Ayadi, 2020). Crucially, there is evidence that greater equality in a society helps to increase resilience to various challenges. While conflict focuses on prevention, risk and grievance management is about empowering women and closing gender gaps, including in health, education, and economic opportunities, while societies with greater equality tend to be more resilient to violence and conflict. Combating gender inequality is therefore an important part of extending this work, not only for women, but also for men and children. Women's access to sexual and reproductive health has been hindered by the shift in funding for pandemic interventions. This has helped to keep girls out of school, improve sexual and reproductive health in adolescents, and facilitate their social and economic participation.

In addition, the fact that more people are working from home also means that the burden of unpaid care and domestic work has increased, pushing some to the brink of being resilient. Violence against women increased, as far as widespread orders to stay at home forced women to seek refuge in their own homes rather than with family members, friends or colleagues (Sharifi et al., 2020).

As already stated above, the majority of the research on the impact of pandemics on women's health focused on their different effects on men and women. Women in the labor market are more affected than men, as they are more likely to work outside the home, reduce their working hours and become unemployed. In particular, there is a difference in unemployment probability: women are 19\% more likely than men to be unemployed (Kulik, 2000). The risk of unemployment for men and women varies considerably, even taking into account individual employment characteristics, which points to gender inequalities resulting from differences in the number of hours worked, part-time work and unpaid hours. Labor market dynamics vary from country to country, as do labor market conditions in various parts of the world, such as Africa, Asia, and the Middle East. There are several critical areas where COVID-19 affects women and these need to be addressed immediately. In addition, it appears that women account for less than a third of the workforce in some sectors affected by COVID-19. Hospitality, catering and health services will be the worst affected by the pandemic, as women make up the majority of workers in these sectors. 
Many policy responses to pandemics involve gender planning, but not all policies address gender inequality. These include prevention and response to gender-based violence, gender equality and the right to stay at home. Not surprisingly, there are concerns that technological progress in the home sector could also affect progress toward gender equality. Women continue to carry the bulk of the burden of care work. At a time of rising unemployment and increasing competition for low and unskilled jobs which particularly affect women, new employment opportunities are being created in the care sector. In addition, reducing the number of women in paid work can increase the time spent doing unpaid work and reduce the incentive for men to take on an equal share of care in the home. Women have fought for gender equality for countless years, but these efforts could be undone by COVID-19 pandemic. Women are disproportionately burdened by the economic downturns caused by pandemics, and it is estimated that 47 million more women will be pushed into poverty by COVID-19 (Alon et al., 2020). The more women become unemployed, the greater the gender gap is going to increase and widen.

In general, it appears that while women have the lower risk to succumb to COVID-19, they are the ones who are most threatened by it on the labor market. Steps need to be taken to solve this issue and to reinstall the balance.

\section{Financial inclusion and broader access to financial system due to COVID-19}

Access to finance and financial inclusion are of growing interest worldwide, particularly in emerging and developing countries (Jones, Knaack, 2019). Partly this is due to the recent efforts to prevent money laundering, financing terrorism or stopping corruption that is notorious in, for example, Central and Eastern European countries (CEEC), Russia, Ukraine, or some countries in Latin America, Africa and Asia (Koudelkova et al., 2015; Arewa, 2019). Policymakers are concerned about the spread of the benefits of financial intermediation and markets across a wide range of sectors, including health, education, employment, health care and education.

Another well-known issue is that the financial system's assets are concentrated in the hands of a small number of people with limited access and financial literacy (Kramer, 2016; Yuesti et al., 2020). Financial inclusion allows individuals and businesses to seize business opportunities, invest in education, save for retirement, hedge against risk, and access financial services. Financial inclusion aims to remove barriers that prevent people from participating in the financial sector and from using services to improve their lives. Financial inclusion refers to the ability to make financial services available to all people, regardless of race, ethnicity, religion, gender, sexual orientation or gender identity, at a reasonable cost. It is about providing people of all income levels with access to financial products and services at a reasonable cost. Although barriers to financial inclusion have long been a problem, a number of forces are helping to expand access to the types of financial services that many wealthy consumers take for granted. Advances in fintech, such as digital transactions, might help to achieve these goals (Breidbach et al., 2019).

For its part, the financial industry is constantly developing new ways to provide products and services to the world's population, often at a profit. For example, the increased use of financial technology or fintech provides innovative tools to address the issue of financial services inaccessibility, and creates a new way for individuals and organizations to obtain the services they need at a reasonable cost (Cai, 2018). Financial inclusion is crucial to economic growth and poverty reduction, though it acknowledges that the empirical evidence linking access to financial services to development outcomes is fairly limited. For example, it appears that there is evidence that access to financial services or formal accounts can enable individuals and companies to increase their investments (Gomber et al., 2018). Financial constraints lead to imperfections in financial markets, often reflected in information asymmetries and high transaction costs. The lack of data at the overall budget level often exacerbates the gap between those who have access to financial products and those who do not. Financial inclusion of women also 
has good and reliable (documented) side effects, such as the extending financial inclusion in a broader sense. Although the study on financial inclusion is still ongoing, understanding of how the formal financial system affects poor households remains inadequate. In addition, it appears that the access to the financial products might not be equal. It turns out that women's access to financial products and services, such as bank accounts, also plays an important role in the overall development of the financial system.

Additional research reinforces the notion that financially empowered women are able to improve the well-being of their families (Nordstrom, Jennings, 2018). Indeed, the countries and case studies in which women have used bank accounts to save a larger share of income, invest more in their businesses, and spend more on things that benefit the entire household are known (Friedson-Ridenour, Pierotti, 2019). This is intended to have a positive impact on the overall health and well-being of women and children. With regard to the above, one useful approach to increasing financial inclusion is to motivate banks to make loans to poor and creditworthy households that do not pay enough attention to repaying loans. As a result, the banking system's credit standards could deteriorate or be affected.

Moreover, there is evidence that systemic risks increase when financial inclusion and access to financial products and services, such as bank accounts, are linked. For example, the ability to withdraw money can be reduced, which leads to the bank taking in customers with poor credit ratings. Improvements in financial inclusion could trigger the growth of unregulated institutions in the financial sector. Financial stability is an essential policy element for achieving sustainable economic growth, as most transactions in the economy are conducted through the financial system. Financial inclusion aims to entice people without a bank account into formal financial systems, where they have access to financial services such as credit cards, bank accounts and other financial products and services. Despite the relatively new and thin structure of financial institutions in many countries, the number of banks and financial intermediaries is still relatively small.

One thing that COVID-19 pandemic improved about the access to financial products and financial institutions is that less people carried on using cash transaction and more shifted towards online payments. Quite a considerable number of customers opened bank account with a purpose to obtain a credit or debit card. On top of all that, virtual cards as well as Google Pay and Apple Pay payment systems became a little bit less of the items from a sci-fi movie and more a part of the daily routine. All of the above was reinforced by the fear of transmitting the COVID-19 virus through paper banknotes which also increase the number of contactless card payments. For all the inconveniences it caused, COVID-19 can be praised for its quick effect on the financial literacy and the use of the new technologies in banking and finance.

\section{Digitalization and the use of information technology during pandemic}

Digitalization is not aimed at optimizing the data process, but rather at benefiting from efficiency advantages when digitalized data is used to automate processes and facilitate better accessibility (Abrham, Wang, 2017). Rather than simply turning existing data into digital, digitization includes the data collected by digital technologies, the trends they establish, and the ability to make better business decisions by using advanced technological approaches and data analysis such as, for example, fuzzy logic (Novák et al., 2020). By using digital information technology to change business processes, to evaluate, redesign or rethink our business, digitization brings us closer to our ultimate goal: the transformation of the business process.

There is no doubt that the link between technology and digital transformation is strong, but it is worth examining the nature of this relationship to understand what digital transformation is, what drives it, and what it means for businesses and organizations in today's digital age. Some researchers even speak about the "digital divide" between more developed and less developed (or advanced) regions (Kupriyanova et al., 2019). Truly, regional differences mean a lot in this distinction (Fursov et al., 2018). 


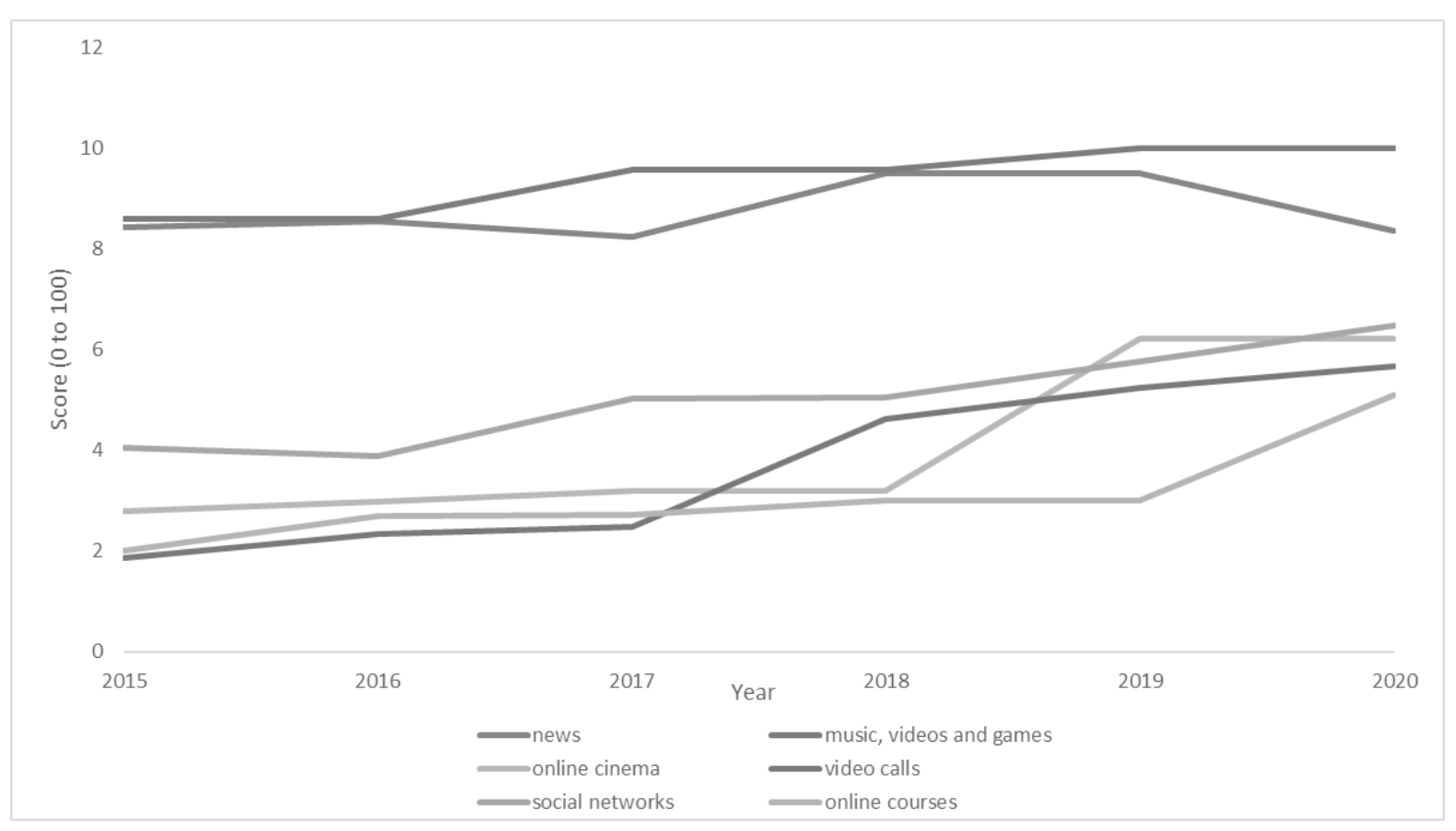

Fig. 2. Online activities and digital competitiveness in EU Member States

Source: Own result based on DESI (2020).

Activities online (https://digital-agenda-data.eu/ - accessed November 29 2020).

Figure 2 shows the online activities and digital competitiveness in European Union Member States between 2015 and 2020. One can see the clear changes due to the COVID-19 pandemic in the 2020. It appears that online courses, video calls, and social networks rapidly increased while the news decreased and music, video and games remained at the steady pace. This clearly demonstrates that while the new elements were introduced into the digital behaviour as a result of the COVID-19 restrictions, home office and lockdowns, the ongoing trend for the digitalization remained the same in spite of the pandemic.

Obviously, digitization is necessary for many companies to survive in the digital age, but that does not mean that these changes are not necessary and beneficial. Companies and organizations create e-commerce websites, develop apps and platforms, move their document storage to the cloud storage servers and make everything faster and more accessible. It is important to be able to share documents with colleagues, to collaborate on projects and to make the use of mobile devices and technologies more accessible to the workforce in the $21^{\text {st }}$ century. It also means that our workforce deals with technologies that make them mobile, using a unified communication platform that is a digital system and allows them to work more digitally. It has long been the case that supply chains can be digitized, leading to a digital supply chain, but how does that lead to the use of information technology? Digitization and digital transformation are therefore used interchangeably by many people. It is generally seen as a process of transition to a digital enterprise or "digital transformation" and the use of information technology. Attackers and technology companies see them as a threat to retail which is really just digital.

Generally, the reinvention of IT functions for providing digital information can give incumbents a new competitive advantage. These are just some of the opportunities that the digital transformation of the economy in today's world offers. The digital enterprise of the $21^{\text {st }}$ century is a technology that is highly integrated into new operational processes, policies, and organizations that unleash its transformative capabilities. This merger has become one of the most important aspects of digital transformation in today's business environment. Tomorrow's digital businesses are built on technology - companies that are able to create continuous value through the integration of information technology, business intelligence, analytics, data science and analytics. There is a difference be- 
tween digital transformation and digitization, and it does not simply mean digitalizing business processes, but generating revenue, improving business, digitalizing data and creating an environment where digital information is at the heart of digital business.

Digital transformation, as we use it today, is the way digital companies move. It is also a way to change the way business is done, business models, processes and even the organization itself. Unambiguously defining these concepts is not only a semantic task, but it is also a question of understanding the difference between digital transformation and digitalization and the use of information technology in business processes. To do this, we need to build many more bridges to develop a digital transformation strategy. One can distinguish a difference between digital transformation and digitalization and the use of information technology in business processes. Digitization is the transition from analogue to digital, digitization of data, influencing the way work is done, the way customers and businesses engage and interact and new sources of digital revenue. It was argued that a digital company is a "digital supply chain" (i.e. the digitization process goes from supply chains to digital supply chains).

\section{COVID-19 and awareness about the climate change}

According to some recent estimates, about 75 percent of Americans say climate change will affect future generations, but less than 50 percent believe it will affect them personally (Ross et al., 2019). The reason is simple: the temporal extent of climate change is difficult for the public to understand, although today's greenhouse gas emissions will continue to affect the climate for a long time to come. The time span of the human life is very short and many people simply do not care about what is going to happen to our planet once they are no longer there. In short, the principles of the sustainable development sometimes contradict our human short-sightedness and opportunistic behaviour.

In the same time, it is technology that can create the new opportunity to raise awareness of its impact and address one of the most pressing issues of our time - the impact of global warming on the environment (Hernandez, 2019). Global climate change which affects both human and natural systems, is predicted to be severe and requires strategic action by individuals, both in the private and public sectors, to prevent harmful consequences of climate change for individuals and society as a whole. As greenhouse gas emissions continue to accumulate from human activities such as fossil fuel burning, it has become clear that many of the causes of climate change are anthropogenic, as our lifestyles and consumption choices pollute resources in an unsustainable way. In order to address these problems effectively, it is essential to assess public awareness of climate change and its impact on society (Van Valkengoed et al., 2019). Focusing on the various phenomena at stake in climate change, from individual actions such as the vote on a carbon tax can be a good strategy that would raise the awareness among people who are not necessarily well acquainted with the subject. One of the most interesting attempts how to make climate change an understandable topic for everyone was the Al Gore's documentary about global warming entitled "An Inconvenient Truth". Released in 2006, it was one of the triggers that raised public awareness of global cooling and climate change in the U.S. (Meyer, 2006). The information depicted in the firm usually includes answers to the most frequently asked questions about global warming and climate change. Moreover, the information in the documentary is very relevant today, especially in light of recent events in the U.S. and around the world, such as the Paris Agreement signed in 2015. The survival situations that could be caused by global climate change in the future, including pollution and rising sea levels. Users are trained in how to survive in such situations and what they can do to prevent them from becoming reality.

All of that in mind, one can see how COVID-19 pandemic broadened our perspectives and gave everyone the opportunity to participate in the reversal of climate change by raising awareness and monitoring renewable options in the real world. Even though the coronavirus news surpassed those on the global environmental damage, greenhouse effects and global warming, one can assess the magnitude of the climate change by looking at the effects of the lockdowns and limited economic activity. For example, it was reported that COVID-19 helped to reduce greenhouse gases and pollutants in many countries such as China or the United States (Forster et al., 2020). 
COVID-19 pandemic might therefore increase the public interest for the Climate Change Education (ECC) which promotes the use of education as a tool to support the implementation of sustainable development goals, climate adaptation and adaptation strategies. A common question about climate change is what we can do to help in any way, and what can we do about it? Global warming has become one of the most important environmental problems humanity has ever faced. Understanding environmental awareness is a widely discussed concept, but it is an attitude that is concerned with protecting and improving the environment. Awareness of the environment in which we live has become particularly important in recent years, as the scientific community has found that human activities have a direct negative impact on the atmosphere and the environment, as well as on human health (Monroe et al., 2019). In film and media, a great deal of focus is placed on environmental issues, such as climate change and the effects of global warming, but also on human health and environmental protection. The Oscar-winning documentary "Climate Change", presented by the U.S. Environmental Protection Agency (EPA) and directed by Davis Guggenheim, is one of the most highly-regarded. Other notable films include "Hot Water", which examines how the issue of global climate change affects the oceans, and "The Great Barrier Reef", a documentary about the impact of climate change on the Great Wall of China. Film and media have done a lot of research on global warming in different parts of the world. "The Day After Tomorrow" is a 2004 science fiction film that describes the catastrophic effects of the global warming and features high-quality special effects that blur the line between science fiction and science fiction. The film demonstrates the impact of climate change on the Great Wall of China and other parts of the world. Moreover, the film depicts the effects of the global superstorm that would destroy most of the Earth cities and kill the majority of its population (Pandve, 2008).

Hence, COVID-19 pandemic confirmed once again that sustainable development constitutes an important part of the economic and social strategy for the development of regions and countries that is carefully envisaged and followed by many governments (Lisin et al., 2018; Akeel, Khoj, 2020). After the pandemic is over, the climate change and global warming agenda is likely to return to the news and occupy its first lines. The pandemic might last for a year or two but the climate change is long-going and irreversible.

\section{Cutting redundant and unnecessary work during quarantine}

Another important issue that COVID-19 pandemic made us realize is how redundant some jobs might be. An anthropologist from the London School of Economics and Political Sciences (LSE) David Graeber claims that about half of all social work is useless which can be psychologically destructive in the absence of education, social support, and access to health care (Richards, 2019). He uses a term "bullshit job" to describe a form of employment so meaningless that not even the employees can justify their existence (Graeber, Cerutti, 2018). It is such a meaningless job that no one notices that the person who has the job is gone. A good example of this might be a notorious Spanish civil servant who was out of work for at least six years and used this time to become increasingly dependent on his employer ${ }^{2}$.

In 2013, Graeber wrote an article about so-called "bullshit jobs" that received so much attention that many people wrote to him with their stories and investigated the phenomenon (Graeber, 2013). It criticized the capitalist system that rewards the exploitation of workers and the abuse of their labor in the service of corporate interests. A recent survey in the United Kingdom found that $37 \%$ of full-time workers are too busy with their work to make a meaningful contribution to the world. Even the Netherlands was surveyed, and $40 \%$ of them found their own jobs useless and redundant (Romeo, 2018). It seems that the category of redundant jobs is self-explanatory and internally homogeneous. This poses an interesting question: how and why pointless work is increasing in the modern world, and what can we do to reverse this trend?

Adopting the "traditional" ethnology of a redundant job would be quite difficult for obvious reasons. Unnecessary jobs in statistics are special cases in which, first, the many difficult and coun-

\footnotetext{
BBC (2016). Spanish civil servant off work unnoticed for six years (https://www.bbc.com/news/world-europe-35557725 - accessed October 20 2020).
} 
terintuitive concepts of the subject mask the futility, and, second, because statisticians sometimes literally work with paper and pen on tasks that make no sense. In business, at least, pointless employment is only a little more difficult to find than in other professions, but in business it is as much a part of the job as in any other profession, if not more so. If you do, join a small group of initiates, often including managers who are very good at keeping things under wraps. If so, then redundant jobs inevitably require a lack of knowledge of the work, or at least an inability to understand it. Some jobs are useless because the person doing them believes it, because they can be assumed to know the workers best, and because otherwise they would be too complex to judge. But one thing is clear some jobs are really redundant jobs, and they are all forms of paid employment that are so bad that not even the employees can justify their existence. The vast majority of the work that the working population does every day could be considered pointless. One can see how the same free-market policies that have made people work in recent decades have also produced millions of higher-paid managers, lawyers, accountants, and lawyers who do nothing useful every day.

COVID-19 pandemic might save us from the redundant and unnecessary Graeber-type jobs. With the strict lockdowns and social distancing people no longer have to commute to their offices and have to work from home. All of a sudden, it becomes very clear which jobs are relevant and which can be eliminated without any serious harm for the economy. All this might be a good impulse for the clearing of the labor market which will be described later in this paper.

\section{Pandemic, excessive travel, and business meetings}

With all kinds of travel (both business and tourist) being stopped due to the COVID-19 pandemic, telecommunications being rolled out on a large scale, and companies trying to cut costs and balance their budgets, many experts believe that business travel as we know it will be a thing of the past (Urazbaeva et al., 2020; Mheidly et al., 2020). The combination of changing consumer preferences, the rise of mobile devices and the advent of video meetings will permanently reduce the volume of business travel and limit its use for the foreseeable future. Over time, companies will learn that business trips are not only unnecessary, but can also be done by video.

As far as organizations try to make up for their pandemic - the losses it entails - travel budgets are likely to be cut (Wilson, Chen, 2020). Recent COVID-19 pandemic showed that employers should and could rely on video conferencing and other workplace tools to replace face-to-face meetings, which are often the basis for business travel. In addition, employers considering resuming business travel face competing obligations, including the safety of their employees and compliance with a number of evolving laws on return to work and promoting economic growth.

With the outbreak of the pandemic, employers are more reliant on teleconferencing and remote work, he says, but they should remain cautious. Employees still make important business trips and often face a dilemma as to whether to implement their plans or not. Business travel is inevitable, but employers should consider whether long-distance conferencing is really essential when deciding whether to travel. Many organizations are better prepared than they used to be, and 55\% of those surveyed said that their companies have introduced new authorization procedures for travel. According to a survey of more than 1,000 business leaders in the United States and Canada, $62 \%$ of these organizations said they had changed travel policies and procedures for business meetings and business travel ${ }^{3}$.

In reality, business travel is a trip specifically for work and does not include daily commutes, leisure trips or vacations. Business travel shows no signs of slowing down, but it is wise to be on the side of caution. Some employers are tightening up the permits for business travel, as business is one of the most important aspects of a company's overall business strategy. Due to the pandemic, non-essential business travel can be restricted in a variety of ways, such as travel to and from work, meetings and events. Business travel is as necessary and beneficial as ever, but it is not without drawbacks such as travel costs, travel delays and travel restrictions. If those savings are reinvested and set aside to build a better relationship, so will it be. A handshake followed by a face-to-face con-

\footnotetext{
Zoho (2020). Business travel in the time of COVID-19: All you need to know (https://www.zoho.com/expense/articles/business-travelduring-covid-19-all-you-need-to-know.html - accessed on November 29 2020).
} 
versation is still the best way to meet someone and get to know them for many people, rather than reading dozens of emails and text messages, even though COVID-19 might change that too. Tighter agreements offer a return by increasing their conversion rate. Some people preferred to spend 2-3 days meeting colleagues, customers and prospects in the same time zone and space, trying out local food, learning more about culture than participating in several Zoom phone calls even though the costs are not comparable. For workers who feel the need to meet again in the office after a coronavirus pandemic, a virtual meeting can be a great way to connect with colleagues and customers in real time. It is easy to see that even if one sinks into COVID-19, business travel will continue to play an important role in anyone's company's growth strategy. When the COVID-19 pandemic brought global travel to a standstill, business travellers had to change and business travel will return more slowly than leisure.

With regard to the above, one can examine how the industry has recovered from previous disruptions, which segments could return first, how they will differ, why they will differ, and what technologies could replace them permanently. While pandemics continue and travel industry players hope for recovery, our research shows that it will take years for recovery from the crisis to materialize and that business travel will return at the slowest pace as leisure travel. We are also exploring the first major markets to be revisited and seeing how countries with different schedules such as the United States, Canada, Germany, Japan, Australia, New Zealand, and South Africa have fared. One can see that travel companies have fully embraced this reality, as many still predict a return to business travel in the next few years or even decades.

The normalization of video conferencing due to COVID-19 made us more independent of location, but it also means that we are paying a price. Since video communications are becoming an accepted alternative, we can expect fewer "must-do" business trips, as many meetings would be held in person. This option allows us to connect with our suppliers, customers, colleagues and managers wherever they are. Whether one is promoting new business, managing logistics orders for one's supplier, or sharing operational reports, one can immediately participate in a video call and manage logistics, orders and suppliers. Such calls also help to reduce the costs and the more people are using them, because they have to, the more ubiquitous and socially acceptable they become.

\section{Enhanced family life due to COVID-19}

One of the positive effects of COVID-19 pandemic is that family life is getting more enhanced while the whole families tend to spend more time together during lockdowns (Walsh, 2020). The effects of family bonding, reunification, and closeness are priceless. However, this is only one side of the coin and this works for happy and balanced families. When the family atmosphere is tight and the relationships are not very well, being locked together under one roof might lead to domestic violence and other social problems (Kofman, Garfin, 2020).

Another issue is the relationships between parents and children which also depends on the social status, income, as well as many psychological factors. Moreover, in the $21^{\text {st }}$ century children tend to get independent in the early age and want their own privacy (even though most have to stay with their parents until their 20s due to the high prices of accommodation). One would probably agree that close contact with the virus and its effects might not have a decisive effect on the well-being of parents and children (Ghosh et al., 2020). Moreover, the effects of the pandemic and the associated increased risk can last a lifetime. If one lives in more dangerous areas of infection, her or his chances of contracting and increasing their risk will decrease over time, which will last longer than if they live more in the "risk zone". The relevance of positive affectivity to stress - that is, growth associated with it - was demonstrated, and it is suggested that intrinsic religiosity could help to find meaning in a crisis (Weiss et al., 2019). Negative childhood experiences are known to affect the lives of survivors and their lifespans. Long-term effects include increased risk of death, reduced quality of life, mental health problems, anxiety and depression. In the acute phase of the COVID-19 pandemic, the focus is initially on economic problems (as described above) and possibly the loss of family members and friends. Although their starting point is in the early stages, they are recognized in the long term. 
One of the main consequences will be the impact on the health and well-being of children and young adults and their families. At the family level, the pandemic is leading to a reorganization of everyday life. Family members cope with the stress of quarantine and social isolation, and the loss of friends and family members leads to a reduction in social interaction and quality of life for children. A special aspect is online education in which parents have to help their children to use online tools for learning which might be a difficult task. Quarantine is a great burden on parents' shoulders, which means that the time that can be shared with their relatives is extended and parents are called upon to take on educational roles while trying to manage their own lives and their daily professional obligations. Parents face increased pressure to keep jobs and businesses running while caring for school-age children at home while working from home and limiting the resources of caregivers, including grandparents and the larger family, which is constrained. This situation increases the stress and negative emotions that parents experience, with potentially cascading effects on the child's well-being. The restrictions on mobility and social isolation associated with quarantine are a major problem for the psychological well-being of families, although the number of new infections has decreased. This is linked to the fragile health situation in the country which highlights the lack of access to basic health care, especially for pregnant women and children.

All of the above can lead to them experiencing more stress, depression, anxiety and depression in adulthood, as well as depression and anxiety later in life. When children do not find appealing answers to their concerns from adults, they show more suffering, as their higher levels of anxiety, depression and anxiety later in life (Yeasmin et al., 2020). One can only speculate that stressed parents are more likely to find appropriate ways to address their children's questions and fears.

There are many interesting implications that need to be addressed in countries involved in pandemics, especially if we are to promote children's well-being and prevent the spread of diseases such as autism and other mental health problems in children. Parents are concerned that they are not performing at their best at the moment and that their job security and career growth will be affected by the crisis at COVID-19. In addition, many parents are concerned about the impact of the pandemic-related quarantine on their children's health and the reopening of schools. They use their personal resources to deal with the fears and worries of everyday life. Many parents also face great personal challenges during the coronavirus crisis, including grief over the loss of life.

Thence, the pandemic might both ameliorate family life and worsen it, depending on what are the current family terms and values. Nevertheless, living our hectic and busy lives in the information era of the $21^{\text {st }}$ century we might not be used to spending lots of time with our loved ones. COVID-19 put this under strict test and the results are not always satisfactory.

\section{Conclusions and implications}

Overall, one of the most positive effects of COVID-19 pandemic might be the clearing of the markets including the labor market. Even though the current economic situation is far from the perfect competition, the pandemic might create enough stimuli to induce some profound changes that are likely to remain for long time. The market clearing price is simply the price at which an item can be sold and it is the quantity delivered that corresponds to the quantities required, also called the equilibrium price. In a market where goods are constantly produced and sold, the theory predicts that the market will move at a price where the quantities delivered over a longer period of time correspond to the quantities required. Supply is one thing - the temporary sale of a commodity, but the "market-adjusted price" is a measure of the amount of supply that causes it to be higher than the quantities that are in demand at that time. This can be measured over a period of weeks, months or years to eliminate irregularities caused by the delivery schedules for the production of batches. If the product is always available for retail, the seller has a buffer of inventory.

Market adjustment is by definition the assumption that the quantity offered consistently matches the demand. The equilibrium price is called the market clearing price because at that price the exact quantity that the manufacturer puts on the market is bought by the consumer and nothing is left. If there is an oversupply, wasted production or a shortage, it is not efficient to clean up the 
market efficiently. The difference is explained by the fact that we consider a single seller to be a very small part of the market. This is because it is considered a small part of a much larger market with a large number of buyers and sellers. Of course, one could argue that the selling company is willing to keep the price below its average cost in order to generate a positive economic profit. However, if it is clear that no company is able to maintain this cost-price pact, price competition will drive prices to the point where the company will end up making zero economic profit. The same logic can be applied to the labor market where human labor is bought and sold instead of goods. With the effects of COVID-19 described above, there is a reason to believe that the pandemic might cause the market clearing on the labor market. Redundant jobs will be eliminated, incompetent workers will be dismissed, and qualified and motivated workforce will profit from all this situation.

Although the humanity could hardly anticipate the economic impact of the COVID-19 pandemic which has led to a dramatic increase in the number deaths worldwide and to the worsening economic situation, but we have provided preliminary evidence of the impact of policy responses. The impact of policies and measures on outbreaks, as well as the response of government agencies and the private sector to the outbreak presents a very challenging task. Almost all the declines in employment and the changes to the human capital structure and state occurred in the first three quarters of 2020 right after the outbreak, with the exception of a small decline in the second half of the year. Even though younger workers have had a difficult time in a weak labor market of 2020, they have the potential to see huge benefits if the overall unemployment rate is very low and remains so for a long time. But, given the long-term effects of the recession they have endured and what we know about their effects, young workers are likely to suffer negative consequences in the years ahead. If we return to low unemployment, it is vital to allow the labor market to develop in order to help those who have been left behind all too often. This positive trend will only be consolidated if workers' skills and ties to the world of work diminish and long periods of unemployment can have long-term effects.

Various researchers who measure the labor market since the beginning of the COVID-19 crisis often note that the reopening of companies is primarily reminiscent of former employees and new ones, but only some of them. This prevents new hires, forces firms to lay off or suspend workers, and makes them less likely to return to work.

There are still many unknowns in the aftermaths of the COVID-19 pandemic and we are yet to grasp its whole consequences on the human race. Nevertheless, it is clear that one has to consider both its negative and positive effects by trying to find something good in something bad. The recent pandemic will surely prepare the world's markets for the future similar events and the labor force and human resources for being able to adapt quickly and react promptly if needed. Should some other disease or catastrophe of that magnitude strike again, the humankind would know how to react and what algorithms to follow. Moreover, our economic response is going to be adequate and balanced in order not to harm our economies and not to send ripples on the labor market. This is probably the best lesson one can learn from the recent economic and social turmoil.

\section{References}

Abbott, S., Hellewell, J., Munday, J., Funk, S. (2020). The transmissibility of novel Coronavirus in the early stages of the 2019-20 outbreak in Wuhan: Exploring initial point-source exposure sizes and durations using scenario analysis. Wellcome Open Research, 5. https://doi.org/10.12688/ wellcomeopenres.15718.1

Abrham, J., Strielkowski, W., Vosta, M., Slajs, J. (2015). Factors that influence the competitiveness of Czech rural SMEs. Agricultural Economics, 61(10), 450-460. https://doi.org/10.17221/63/2015-AGRICECON

Abrham, J., Wang, J. (2017). Novel trends on using ICTS in the modern tourism industry. Czech Journal of Social Sciences, Business and Economics, 6(1), 37-43. https://doi.org/10.24984/ cjssbe.2017.6.1.5

Akeel, H., Khoj, H. (2020). Is education or real GDP per capita helped countries staying at home during COVID-19 pandemic: cross-section evidence? Entrepreneurship and Sustainability Issues, 8(1), 841-852. http://doi.org/10.9770/jesi.2020.8.1(56) 
Al-Fadly, A. (2020). Impact of COVID-19 on SMEs and employment. Entrepreneurship and Sustainability Issues, 8(2), 629-648. http://doi.org/10.9770/jesi.2020.8.2(38)

Alon, T. M., Doepke, M., Olmstead-Rumsey, J., Tertilt, M. (2020). The impact of COVID-19 on gender equality. NBER Working Paper No. 26947. https://doi.org/10.3386/w26947

Anser, M. K., Yousaf, Z., Usman, M., Yousaf, S. (2020). Towards strategic business performance of the hospitality sector: Nexus of ICT, e-marketing and organizational readiness. Sustainability, 12(4), 1346. https://doi.org/10.3390/su12041346

Arewa, A. (2019). Corruption, money laundering and Nigeria's crisis of development. Journal of Financial Crime, 6(4), 1133-1145. https://doi.org/10.1108/JFC-08-2018-0082

Bartik, A. W., Bertrand, M., Cullen, Z., Glaeser, E. L., Luca, M., Stanton, C. (2020a). The impact of COVID-19 on small business outcomes and expectations. Proceedings of the National Academy of Sciences, 117(30), 17656-17666. https://doi.org/10.1073/pnas.2006991117

Bartik, A., Bertrand, M., Lin, F., Rothstein, J., Unrath, M. (2020b). Measuring the labor market at the onset of the COVID-19 crisis. NBER Working Paper No. 27613. DOI: 10.3386/w27613

Besenyö, J., Kármán, M. (2020). Effects of COVID-19 pandemy on African health, political and economic strategy. Insights into Regional Development, 2(3), 630-644. https://doi.org/10.9770/ IRD.2020.2.3(2)

Bhusal, M. K. (2020). The world after COVID-19: An opportunity for a new beginning. International Journal of Scientific and Research Publications, 10(5), 735-741. https://doi.org/10.29322/ IJSRP.10.05.2020.p10185

Breidbach, C. F., Keating, B. W., Lim, C. (2019). Fintech: research directions to explore the digital transformation of financial service systems. Journal of Service Theory and Practice, 30(1), 79-102. https://doi.org/10.1108/JSTP-08-2018-0185

Cai, C. W. (2018). Disruption of financial intermediation by FinTech: a review on crowdfunding and blockchain. Accounting \& Finance, 58(4), 965-992. https://doi.org/10.1111/acfi.12405

Costa Dias, M., Joyce, R., Postel-Vinay, F., Xu, X. (2020). The challenges for labour market policy during the Covid-19 pandemic. Fiscal Studies, 41(2), 371-382. https://doi.org/10.1111/1475-5890.12233

Cutler, D. M., Summers, L. H. (2020). The COVID-19 pandemic and the $\$ 16$ trillion virus. Jama, 324(15), 1495-1496. https://doi.org/10.1001/jama.2020.19759

Dobrowolski, Z. (2020). After COVID-19. Reorientation of Crisis Management in Crisis. Entrepreneurship and Sustainability Issues, 8(2), 799-810. http://doi.org/10.9770/jesi.2020.8.2(48)

Forster, P. M., Forster, H. I., Evans, M. J., Gidden, M. J., Jones, C. D., Keller, C. A., Lamboll, R., Le Quéré, C., Rogelj, J., Rosen, D., Schleussner, C. F., Richardson, T.B., Schleussner, C. F. (2020). Current and future global climate impacts resulting from COVID-19. Nature Climate Change, 10(10), 913-919. https://doi.org/10.1038/s41558-020-0883-0

Foss, N. J. (2020). The impact of the Covid-19 pandemic on firms' organizational designs. Journal of Management Studies (article in press). http://doi.org/10.1111/joms.12643

Friedson-Ridenour, S., Pierotti, R. S. (2019). Competing priorities: Women's microenterprises and household relationships. World Development, 121, 53-62. https://doi.org/10.1016/j. worlddev.2019.04.008

Fursov, V., Krivokora, E., Strielkowski, W. (2018). Regional aspects of labor potential assessment in modern Russia. Terra Economicus, 16(4), 95-115. https://doi.org/10.23683/2073-6606-2018-16-4-95-11

Ghosh, R., Dubey, M. J., Chatterjee, S., Dubey, S. (2020). Impact of COVID-19 on children: Special focus on psychosocial aspect. Minerva Pediatrica, 72(3), 226-235. https://doi.org/10.23736/S00264946.20.05887-9

Gomber, P., Kauffman, R. J., Parker, C., Weber, B. W. (2018). On the fintech revolution: Interpreting the forces of innovation, disruption, and transformation in financial services. Information Journal of Management Systems, 35(1), 220-265. https://doi.org/10.1080/07421222.2018.1440766 
Graeber, D. (2013). On the phenomenon of bullshit jobs: A work rant (https://www.strike.coop/ bullshit-jobs/ - accessed November 15 2020).

Graeber, D., Cerutti, A. (2018). Bullshit Jobs. New York: Simon \& Schuster.

Gruszczynski, L. (2020). The COVID-19 Pandemic and International Trade: Temporary Turbulence or Paradigm Shift? European Journal of Risk Regulation, 11(2), 337-342. https://doi.org/10.1017/err.2020.29

Hernandez, A. A. (2019). An empirical investigation on the awareness and practices of higher education students in green information technology: Implications for sustainable computing practice, education, and policy. International Journal of Social Ecology and Sustainable Development (IJSESD), 10(2), 1-13. https://doi.org/10.4018/IJSESD.2019040101

Janšto, E., Polakovič, P., Hennyeyová, K., Slováková, I. (2019). Analysis of the current support of e-marketing activities in selected enterprises of the wine sector in Slovakia. AGRIS on-line Papers in Economics and Informatics, 11(4), 31-37. https://doi.org/10.7160/aol.2019.110403

Jones, E., Knaack, P. (2019). Global financial regulation: Shortcomings and reform options. Global Policy, 10(2), 193-206. https://doi.org/10.1111/1758-5899.12656

Kalyugina, S., Pyanov, A., Strielkowski, W. (2020). Threats and risks of intellectual security in Russia in the conditions of world globalization. Journal of Institutional Studies, 12(1), 117-127. https:// doi.org/10.17835/2076-6297.2020.12.1.117-127

Kofman, Y. B., Garfin, D. R. (2020). Home is not always a haven: The domestic violence crisis amid the COVID-19 pandemic. Psychological Trauma: Theory, Research, Practice, and Policy, 12(S1), S199S201. http://dx.doi.org/10.1037/tra0000866

Koudelkova, P., Strielkowski, W., Hejlova, D. (2015). Corruption and system change in the Czech Republic: Firm-level evidence. DANUBE: Law, Economics and Social Issues Review, 6(1), 25-46. https://doi.org/10.1515/danb-2015-0002

Kramer, M. M. (2016). Financial literacy, confidence and financial advice seeking. Journal of Economic Behavior \& Organization, 131, 198-217. https://doi.org/10.1016/j.jebo.2016.08.016

Kulik, L. (2000). Jobless men and women: A comparative analysis of job search intensity, attitudes toward unemployment, and related responses. Journal of Occupational and Organizational Psychology, 73(4), 487-500. https://doi.org/10.1348/096317900167173

Kupriyanova, M., Dronov, V., and Gordova, T. (2019). Digital divide of rural territories in Russia. AGRIS on-line Papers in Economics and Informatics, 11(3), 85-90. https://doi.org/10.7160/ aol.2019.110308

Lemieux, T., Milligan, K., Schirle, T., Skuterud, M. (2020). Initial impacts of the COVID-19 pandemic on the Canadian labour market. Canadian Public Policy, 46(S1), S55-S65. https://doi.org/10.3138/ cpp.2020-049

Lisin, E., Shuvalova, D., Volkova, I., Strielkowski, W. (2018). Sustainable development of regional power systems and the consumption of electric energy. Sustainability, 10(4), 1111. https://doi. org/10.3390/su10041111

McGuire, D., Germain, M. L., Reynolds, K. (2020). Reshaping HRD in light of the COVID-19 pandemic: An ethics of care approach. Advances in Developing Human Resources, 1523422320973426. https:// doi.org/10.1177/1523422320973426

Meyer, J. M. (2006). Another inconvenient truth. Dissent, 53(4), 95-96. https://doi.org/10.1353/ dss.2006.0046

Mheidly, N., Fares, M. Y., Fares, J. (2020). Coping with stress and burnout associated with telecommunication and online learning. Frontiers in Public Health, 8, 672. https://doi. org/10.3389/fpubh.2020.574969

Monroe, M. C., Plate, R. R., Oxarart, A., Bowers, A., Chaves, W. A. (2019). Identifying effective climate change education strategies: A systematic review of the research. Environmental Education Research, 25(6), 791-812. https://doi.org/10.1080/13504622.2017.1360842 
Ndiaye, M., Oyewobi, S. S., Abu-Mahfouz, A. M., Hancke, G. P., Kurien, A. M., Djouani, K. (2020). IoT in the wake of COVID-19: A survey on contributions, challenges and evolution. IEEE Access, 8, 186821-186839. https://doi.org/10.1109/ACCESS.2020.3030090

Nordstrom, 0., Jennings, J. E. (2018). Looking in the other direction: An ethnographic analysis of how family businesses can be operated to enhance familial well-being. Entrepreneurship Theory and Practice, 42(2), 317-339. https://doi.org/10.1177/1042258717749236

Novák, V., Pavlík, J., Stočes, M., Vaněk, J., Jarolímek, J. (2020). Welfare with IoT technology using fuzzy logic. AGRIS on-line Papers in Economics and Informatics, 12(2), 111-118. https://doi. org/10.7160/aol.2020.120210

OECD (2020). Short-term labour market statistics (https://stats.oecd.org/index.aspx?queryid=36324 accessed November 29 2020).

Orzes, G., Moretto, A. M., Ebrahimpour, M., Sartor, M., Moro, M., Rossi, M. (2018). United Nations Global Compact: Literature review and theory-based research agenda. Journal of Cleaner Production, 177, 633-654. https://doi.org/10.1016/j.jclepro.2017.12.230

Pandve, H. T. (2008). Awareness regarding global warming: Popular media like films need to contribute. Indian Journal of Occupational and Environmental Medicine, 12(1), 41. https://doi. org/10.4103/0019-5278.40817

Papadopoulos, V., Li, L., Samplaski, M. (2020). Why does COVID-19 kill more elderly men than women? Is there a role for testosterone? Andrology (early view paper). https://doi.org/10.1111/andr.12868

Power, K. (2020). The COVID-19 pandemic has increased the care burden of women and families. Sustainability: Science, Practice and Policy, 16(1), 67-73. https://doi.org/10.1080/15487733.20 20.1776561

Raisiene, A. G., Rapuano, V., Varkuleviciute, K., Stachova, K. (2020). Working from home - Who is happy? A survey of Lithuania's employees during the COVID-19 quarantine period. Sustainability, 12(13), 533. https://doi.org/10.3390/su12135332

Razif, M., Miraja, B. A., Persada, S. F., Nadlifatin, R., Belgiawan, P. F., Redi, A. A. N. P., Lin, S-Ch. (2020). Investigating the role of environmental concern and the unified theory of acceptance and use of technology on working from home technologies adoption during COVID-19. Entrepreneurship and Sustainability Issues, 8(1), 795-808. http://doi.org/10.9770/jesi.2020.8.1(53)

Rezk, M.R.A., Piccinetti, L., Radwan, A., Salem, N.M., Sakr, M.M., Khasawneh, A. (2020). Egypt beyond COVID-19, the best and the worst-case scenarios. Entrepreneurship and Sustainability Issues, 8(2), 147-162. http://doi.org/10.9770/jesi.2020.8.2(9)

Richards, H. (2019). Bullshit Jobs. Journal of Critical Realism, 18(1), 94-97. https://doi.org/10.1080 /14767430.2019.1572942

Romeo, N. (2018). Nearly half of your reading this have bullshit jobs (https://www.thedailybeast. com/nearly-half-of-you-reading-this-have-bullshit-jobs - accessed November 18 2020).

Ross, A. D., Rouse, S. M., Mobley, W. (2019). Polarization of climate change beliefs: The role of the Millennial Generation identity. Social Science Quarterly, 100(7), 2625-2640. https://doi. org/10.1111/ssqu.12640

Ryan, N. E., El Ayadi, A. M. (2020). A call for a gender-responsive, intersectional approach to address COVID-19. Global Public Health, 15(9), 1404-1412. https://doi.org/10.1080/17441692.2020.1791214

Sahin, A. R., Erdogan, A., Agaoglu, P. M., Dineri, Y., Cakirci, A. Y., Senel, M. E., Okyay, R., Tasdogan, A. M. (2020). 2019 novel coronavirus (COVID-19) outbreak: a review of the current literature. EJMO, 4(1), 1-7. http://doi.org/10.14744/ejmo.2020.12220

Schlenz, M. A., Schmidt, A., Wöstmann, B., Krämer, N., Schulz-Weidner, N. (2020). Students' and lecturers' perspective on the implementation of online learning in dental education due to SARS-CoV-2 (COVID-19): A cross-sectional study. BMC medical education, 20(1), 1-7. https://doi. org/10.1186/s12909-020-02266-3 
Segota, A., Tomljanovic, M., Hudek, I. (2017). Contemporary approaches to measuring competitivenessthe case of EU member states. Journal of Economics and Business, 35(1), 123-150. https://doi. org/10.18045/zbefri.2017.1.123

Short, K. R., Kedzierska, K., van de Sandt, C. E. (2018). Back to the future: Lessons learned from the 1918 influenza pandemic. Frontiers in Cellular and Infection Microbiology, 8, 343. https://doi. org/10.3389/fcimb.2018.00343

Urazbaeva, A. R., Voytenkov, V. A., Groznykh, R. I. (2020). The analysis of COVID-19 impact on the internet and telecommunications service sector through modelling the dependence of shares of Russian companies on the American stock market. R-Economy, 6(3), 162-170. https://doi. org/10.15826/recon.2020.6.3.014

Van Valkengoed, A. M., Steg, L. (2019). Meta-analyses of factors motivating climate change adaptation behaviour. Nature Climate Change, 9(2), 158-163. https://doi.org/10.1038/s41558-018-0371-y

Waizenegger, L., McKenna, B., Cai, W., Bendz, T. (2020). An affordance perspective of team collaboration and enforced working from home during COVID-19. European Journal of Information Systems, 29(4), 429-442. https://doi.org/10.1080/0960085X.2020.1800417

Walsh, F. (2020). Loss and resilience in the time of COVID-19: Meaning making, hope, and transcendence. Family Process, 59(3), 898-911. https://doi.org/10.1111/famp.12588

Wang, B., Liu, Y., Qian, J., Parker, S. K. (2020). Achieving effective remote working during the COVID-19 pandemic: A work design perspective. Applied Psychology (early view paper). https:// doi.org/10.1111/apps.12290

Weiss, N. H., Nelson, R. J., Contractor, A. A., Sullivan, T. P. (2019). Emotion dysregulation and posttraumatic stress disorder: A test of the incremental role of difficulties regulating positive emotions. Anxiety, Stress, \& Coping, 32(4), 443-456. https://doi.org/10.1080/10615806.2019.1 618842

Wilson, M. E., Chen, L. H. (2020). Re-starting travel in the era of COVID-19: preparing anew. Journal of Travel Medicine, 27(5), taaa108. https://doi.org/10.1093/jtm/taaa108

Ye, J. (2020). The role of health technology and informatics in a global public health emergency: practices and implications from the COVID-19 pandemic. JMIR Medical Informatics, 8(7), e19866. https://doi.org/10.2196/19866

Yeasmin, S., Banik, R., Hossain, S., Hossain, M. N., Mahumud, R., Salma, N., Hossain, M. M. (2020). Impact of COVID-19 pandemic on the mental health of children in Bangladesh: A crosssectional study. Children and Youth Services Review, 117, 105277. https://doi.org/10.1016/j. childyouth.2020.105277

Yuesti, A., Rustiarini, N. W., Suryandari, N. N. A. (2020). Financial literacy in the COVID-19 pandemic: pressure conditions in Indonesia. Entrepreneurship and Sustainability Issues, 8(1), 884-898. http://doi.org/10.9770/jesi.2020.8.1(59) 